\title{
SUITABILITY OF POTATO VARIETIES AND BREEDING MATERIAL FOR GROWING UNDER STRESSFUL CONDITIONS IN NORTH KURZEME REGION OF LATVIA
}

\author{
Lidija VOJEVODA, Institute of Agroecological Resources and Economics, Struktoru street 14, Riga, 1039, Latvia; \\ lidija.vojevoda@arei.lv (corresponding author) \\ Ilze SKRABULE, Institute of Agroecological Resources and Economics, Struktoru street 14, Riga, 1039, Latvia; \\ ilze.skrabule@arei.lv
}

Potato (Solanum tuberosum L.) is mostly suitable for growing in moderate climate conditions at temperature $20^{\circ} \mathrm{C}$. Yields are influenced by many factors: soil characterization, available nutrients, distribution of pests and weeds, agrotechnology, genotype or variety and climatic conditions during the vegetation period. In recent years' summary of meteorological conditions (precipitation and air temperature), showed that stressful conditions during the vegetation period had a diverse influence on the growth and development of plants. Excess or lack of humidity in soil or drought and heat affected the size and shape of the potato tubers. The heat stress is the problem of agriculture in many regions of the world in the last years.

The aim of the study was to evaluate cultivars and clones from the breeding material under the stress conditions at the Stende Research Centre. The field trials were set up due to project of the Latvian Ministry of Agriculture: "Evaluation of breeding material to implement integrated and organic agriculture crop production technologies"(2015-2018). The article summarizes results of nine potato clones and nine varieties in both integrated and organic systems during 2017-2018, when 2018 was one of the driest and hottest in the last 100 years. The evaluation of the varieties and breeding material phenological phases in two years showed that germination and flowering differed from year to year. Due to hot and dry weather conditions flowering was weak for several varieties and the bud flowering was observed. In 2018 germination for some varieties was slower compared to the previous year, but for many varieties ('Lenora', 'Prelma', 'Imanta') and breeding material germination was not delayed (Table 1). The earlyest germination and flowering were observed for variety 'Monta'. Earlier germination compared to other varieties and clones was recorded to S01085-21 and S03067-33 and the variety 'Rigonda'. In the organic field earlier germination was observed for the varieties 'Rigonda', 'Monta', 'Prelma' and clones S01085-21, S07169-35.

The yield of varieties and breeding material lines in both years was good but still lower tuber yields were obtained in the integrated growing system and only one line (S01085-21) and variete 'Gundega' had significantly higher yield in comparison 2017. In the organic growing system tuber yields of all varieties and breeding material lines were significantly lower than the 2017 year. Yield reduction is not significant for 3 breeding material lines: S10063-128, 19922.29 and S2008-6.5.

Keywords: climate impact, integratedgrowing system, organicgrowing system, phenological phases, potato varieties, tuber yield

\section{INTRODUCTION}

Potatoes are suitable for moderate climate zone. The best development of plants is when the soil temperature is not lower than $7-8^{\circ} \mathrm{C}$ and higher than $+25^{\circ} \mathrm{C}$ (Haverkort, 1990). The optimum of air temperature for blossoming is $+20-21^{\circ} \mathrm{C}$, but the shoots start to grow at $+5-6^{\circ} \mathrm{C}$ and have stopped blossom and tuber growth at $+30{ }^{\circ} \mathrm{C}$ (Stol et al. 1991; Reynolds and Ewing 1989) and freezes at -1-1.5 ${ }^{\circ} \mathrm{C}$ (De Temmerman et al. 2002). Potatoes are humidity required plants. Precipitation has the positive effect on the growth of the foliage in the first stage of the vegetation period and on the formation and mass of tubers in the second part of the vegetation period.

Drought (lack of moisture in soil) effects negatively plant development and tubers appearance and yield. Scientists from Check Republic were established that reaction of cultivars on heat stress were depending from plants growing stage and the largest problem are tubers with physiological defects (Rukaszewska, 2017). It has been investigated that even humidity conditions provide optimal turgor in tuber cells, and increase tuber resistance to mechanical injuries (Skrabule, 2003). The composition of sugar and starch in tubers also varies depending to annual meteorological conditions (Skrabule, 2003; Dale and Mackay, 1994). After to the results of the research, the starch content of the evaluated varieties varied from year to year, which can be explained by different meteorological conditions of the each year (Murniece, 2010). Several scientists have used simulation models to study the effect of global warming on potato yields and predicted that yields may increase with longer vegetation in England - (Davies et al.1996); in Scotland (Peins et al. 1996) and in Finland (Carter et al. 1996). However, overall crop decline was predicted in the US (Rosenzweig et al., 1996). In many region potato yields could decline in the future due to temperature increases, but could be partially prevented by plant adaptation to climatic conditions (Hijmans R.J., 2003). Scientists have found that increases of potato yield in average of $20 \%$ is

Copyright (C) 2019 The Authors. Published by Vytautas Magnus University. This is an open-access article distributed under the terms of the Creative Commons Attribution License (CC BY 4.0), which permits unrestricted use, distribution, and reproduction in any medium, provided the original author and source are credited. 
connected by global warming and increasing the concentration of CO2 in the atmosphere (De Temmerman et al. 2002). However, the magnitude and persistence the influence of this effect under field conditions is very uncertain and efforts should be made to avoid yield reduction due to temperature changes. Latvia is also impacted by climate change which affects crop development and yields. Therefore it is important to know reaction of potato varieties respond to unregulated environmental factors. The research was carried out with the aim to select potatoes varieties with better adaptivity and less responsivity to abnormal meteorological conditions.

\section{MATERIALS AND METHODS}

The research was arranged at AREI Stende Research Center 2017 - 2018 in two growing systems: integrated and organic. The trial was arranged in 4 replicates, the variants were randomized. The trial in integrated growing system was carried out in sod podzolized, glazed, loam soil, organic mater content $2.2-2.6 \%$, P2O5 - 127 - $239 \mathrm{mg} \mathrm{kg} \mathrm{-} \mathrm{1,} \mathrm{K2O} \mathrm{-}$ 147 - $197 \mathrm{mg} \mathrm{kg} \mathrm{-} 1$ and pHKCL - 6.3 - 6.7 in 2017 year and humus content 1.9\%, P2O5 - $151 \mathrm{mg} \mathrm{kg-1,} \mathrm{K2O} \mathrm{-} 201 \mathrm{mg}$ $\mathrm{kg}-1$, pHKCL - 5.0 - 6.0 in 2018. In the organic growing system, the evalution was carried out in sod podzolized glazed loamy soil with soil reaction $\mathrm{pH} \mathrm{KCl} \mathrm{-} 5.6-6.3$, organic matter content 3.3\%, P2O5 - $250 \mathrm{mg} \mathrm{kg-1} \mathrm{and} \mathrm{K2O} \mathrm{-} 140 \mathrm{mg}$ $\mathrm{kg}-1$. The potatoes were planted by hand within a distance of $0.3 \mathrm{~m}$ between tubers and $0.80 \mathrm{~m}$ between furrows, in the integrated field, and $0.70 \mathrm{~m}$ in the organic field in the third decade of May. In the integrated field before the planting complex fertilizers NPK 8:12:23 norm - $500 \mathrm{~kg}$ ha-1 ( $\mathrm{N}$ pure material - $40 \mathrm{~kg}$ ha $-1, \mathrm{P} 2 \mathrm{O} 5-60 \mathrm{~kg} \mathrm{ha}-1, \mathrm{~K} 2 \mathrm{O}-115 \mathrm{~kg}$ ha -1) was used. Fertilizer NS $150 \mathrm{~kg}$ ha -1, and leaf fertilizer - Zoom 2 L ha-1 3 times during vegetation was apllied. In the integrated field, weeds, late blight (Phytophora infestans), early blight (Alternaria solani;) were chemically controled by pesticides. In the organic field, weeds were controlled by harrowing, and Colorado beetles (Leptinotarsa decimlineata) were controlled manually. There were 9 varieties and 9 breeding clones under investigation: 'Rigonda', 'Monta', 'Lenora', 'Prelma', 'Brasla', 'Imanta', 'Jogla', 'Gundega', 'Kuras', S01085-21; S07169-35; S18699-37; S04065-2; S07131-15; S10063-128; S10063-45; S2008-6.5; 29.2.1992.

\section{Climatic conditions.}

In 2017 climatic conditions for the development and growth of potatoes were favourable, exception in May and early June $\left(+10^{\circ} \mathrm{C}\right)$ which did no promoted rapid germination of potato plants. Flowering time was delayed. In June and July the average of air temperatures were below norm, only the third decade of July was warmer. $\left(+15.5^{\circ} \mathrm{C}\right.$ and $55.5 \mathrm{~mm}$ precipitation). During summer months - June, July, August moderately warm and favorable conditions for the development of potato tubers took place. Precipitation in June was just above normal, and July and August were even relatively dry. Although it was more rainy at the beginning of the in August, it was not long lasting and there was no heavy rainfall, but more often it was raining.

In 2018 climatic conditions were unfavorable for the potatoes, drought and heat did not promote germination of seed tubers. According to the meteorological data, the soil temperature and in June exceeded $+25-+27^{\circ} \mathrm{C}$ in the end of May, which is not suitable for development of germ. May of this year was recognized as the tenth driest and hottest month of the last 100 years. The rainfall was $14 \mathrm{~mm}$ in May.Tuber sprouting was very slow and uneven.

Flowering for varieties and clones was also very poor. Several varieties of flower buds withered due to heat and drought.

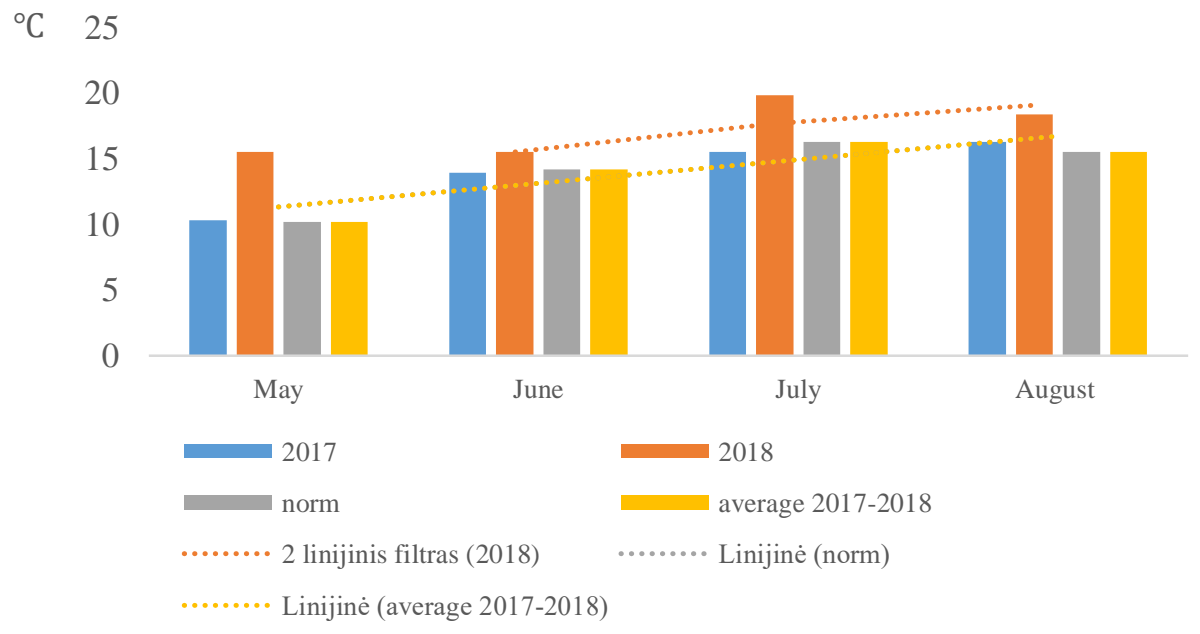

Figure 1. Average temperature, ${ }^{\circ} \mathrm{C} 2017-2018$

The average air temperature June was $+15.5^{\circ} \mathrm{C},+1.3^{\circ} \mathrm{C}$ above the monthly mean. In July the average of air temperature was $+19.8^{\circ} \mathrm{C}$ it was the same as the average in Latvia.In August the average temperature was $+18.4^{\circ} \mathrm{C}$, or $2.9^{\circ} \mathrm{C}$ above the monthly long term mean. The monthly minimum of air temperature is $+5.4^{\circ} \mathrm{C}$ in August 22 and the maximum air temperature was $+30^{\circ} \mathrm{C}$ in August 9 .

The total rainfall in June was $35.8 \mathrm{~mm}$, or $62.8 \%$ from the monthly norm (80 mm). 
In July sum of precipation was $37.5 \%$ of norm. Hot and dry weather affected potato blooms and were early blight (caused by Alternaria solani) was developed but late blight (induced by Phytophora infestans) was not observed.

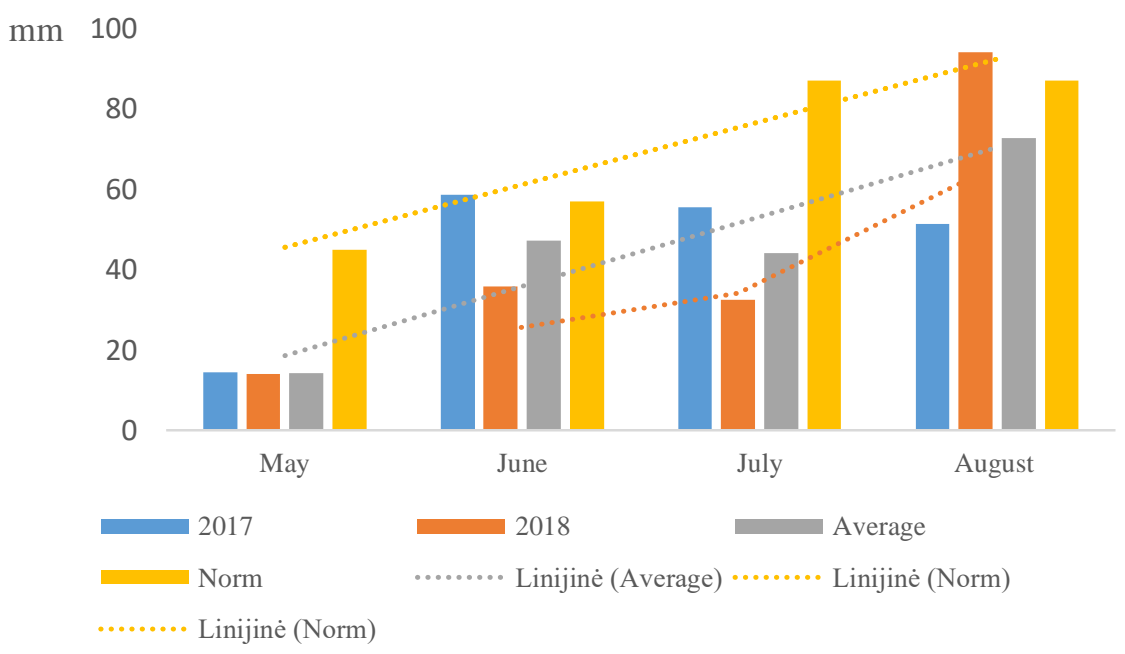

Figure 2. Total precipitation,mm

Total rainfall in August was $94.1 \mathrm{~mm}$, or $8.2 \%$ above the monthly average $(87 \mathrm{~mm})$ and the highest rainfall was in the second decade - $56 \mathrm{~mm}$. Potato tubers continued to grow very fast.

\section{RESULTS AND DISCUSSION}

The evaluation of the varieties and breeding material phenological phases in two years showed that germination and flowering differed from year to year. Due to hot and dry weather conditions flowering was weak for several varieties and the bud flowering was observed. Other researchers (Stol et al. 1991; Reynolds and Ewing 1989) observed that due to the influence of hot and dry weather potato blooms are low. In 2018 germination for some varieties was slower compared to the previous year, but for many varieties ('Lenora', 'Prelma', 'Imanta') and breeding material germination was not delayed (Table 1). The fastest germination and the earliest flowering were observed for variety 'Monta'. Earlier germination compared to other varieties and lines was recorded to S01085-21 and S03067-33 and the variety 'Rigonda'. In the organic field earlier germination was observed for the varieties 'Rigonda', 'Monta', 'Prelma' and lines S01085-21, S07169 -35. Varieties and breeding lines may be able to adapt to stress conditions. Studies elsewhere have also shown that plants can adapt to meteorological conditions (Hijmans R.J., 2003).

1 Table. Phenological observations, 2017-2018

\begin{tabular}{|l|c|c|c|c|}
\hline \multirow{2}{*}{$\begin{array}{c}\text { Varieties/breeding } \\
\text { materials }\end{array}$} & \multicolumn{2}{|c|}{ Integrated field } & \multicolumn{2}{c|}{ Organic field } \\
\cline { 2 - 5 } & $\begin{array}{l}\text { Days after planting, } \\
\text { 2017 Germination }\end{array}$ & $\begin{array}{l}\text { Days after planting, } \\
\text { 2018 Flowering }\end{array}$ & $\begin{array}{l}\text { Days after planting, 2017 } \\
\text { Germination }\end{array}$ & $\begin{array}{l}\text { Days after planting, } \\
\text { 2018 Flowering }\end{array}$ \\
\hline Rigonda & 24 & 58 & 20 & 50 \\
\hline Monta & 24 & 58 & 17 & 50 \\
\hline Lenora & 28 & 60 & 28 & 56 \\
\hline Jogla & 30 & 61 & 22 & 54 \\
\hline Brasla & 28 & 58 & 24 & 59 \\
\hline Prelma & 24 & 60 & 27 & 59 \\
\hline Imanta & 27 & 64 & 23 & 56 \\
\hline Gundega & 28 & 67 & 24 & 56 \\
\hline Kuras & 28 & 64 & 22 & 56 \\
\hline S01085-21 & 24 & 58 & 22 & 57 \\
\hline S07007.33 & 26 & 62 & 24 & 56 \\
\hline S07169.35 & 28 & 60 & 28 & 57 \\
\hline 18699.37 & 32 & 63 & 24 & 57 \\
\hline S07135-15 & 28 & 62 & 24 & 59 \\
\hline S04065-2 & 28 & 64 & 24 & 59 \\
\hline S10063-128 & 28 & don't bloom & 26 & don't bloom \\
\hline S10063-45 & 29 & 64 & 24 & 59 \\
\hline 19922.29 & 28 & 66 & 24 & don't bloom \\
\hline 2008-6.5 & 28 & & & \\
\hline
\end{tabular}

Potatoes were harvested in the first decade of September. Evaluating the yield of varieties and breeding clones between years, lower tuber yields were obtained in the integrated growing system, including hot and dry 2018, and only 
one line S01085-21 (53.1t ha-1) and the variety 'Gundega' (55.25 t) ha-1) yield was significantly (Ffact> Fcrit) higher than in 2017 (Fig. 3).

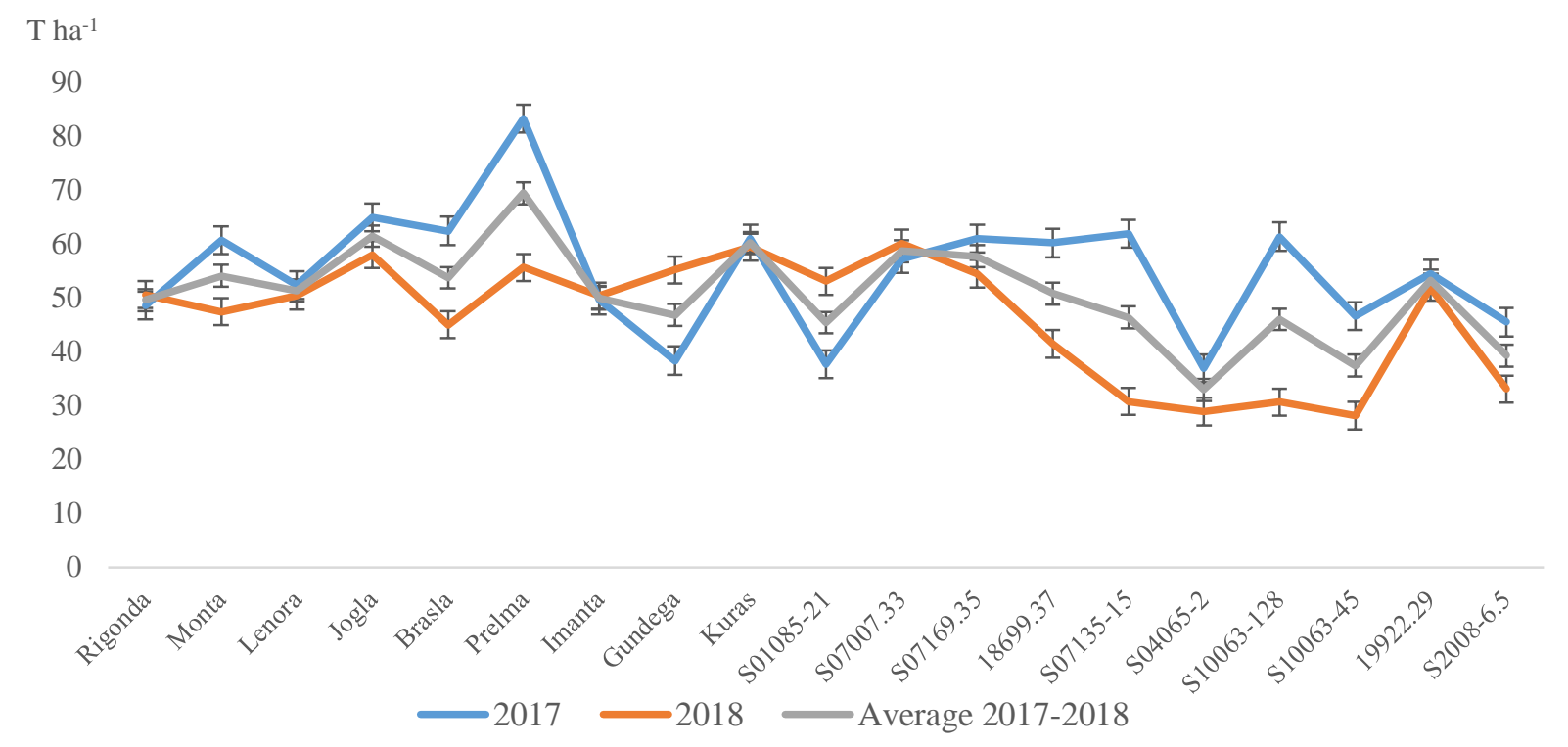

Figure 3. Average potato tuber yeld, in integrated field, $\mathrm{t} \mathrm{ha}^{-1}(\mathrm{RS} 005=4.38)$

In organic growing systems, tuber yields for varieties and breeding clones were significantly (Ffact> Fcrit) lower than in 2017, only variete "Gundega" and lines S10063-128, 19922.29 and S2008-6.5 did not have significant yield reduction (Ffakt <F crit) (Fig.4).

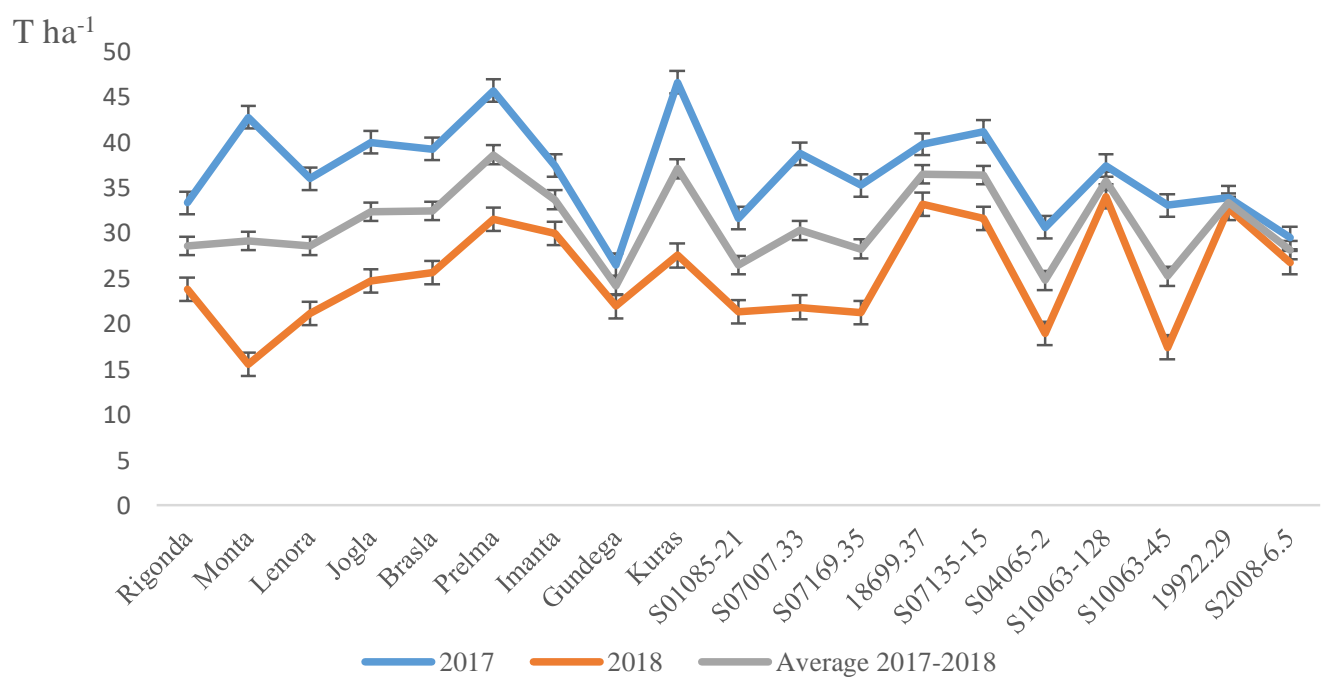

Figure 4. Average potato tuber yeld, in organic field, $\mathrm{t}^{-1}(\mathrm{RS} 005=4.25)$

Other Czech and US scientists (Rukaszewska, 2017; Rosenzweig et al., 1996) convinced that heat and drought negatively affects plant development and tubers yield. In August 2003, Europe recorded its worst unprecedented heat wave with record breaking temperatures surpassing $40^{\circ} \mathrm{C}$ in Belgium. Severe prolonged droughts hit the 2007 and 2011 spring seasons causing severe crop damage. In May 2009, storms with lightning and hail resulted in devastating destruction across the country. In November 2010, excessive rainfall of up to $90 \mathrm{~mm}$ during 3 days triggered the worst flooding in 50 years. All of these natural hazards were caused by "severe" or "extreme" weather events. Since more than half of the Belgian territory is managed by the agricultural sector, extreme and severe weather events have significant impacts on agroecosystems, their functions and services. These extreme events are likely to increase under climate change.

\section{CONCLUSIONS}

In 2018 in integrated growing system the yield of cultivars and breeding clones was significantly lower than in 2017 (Ffact>Fcrit), except variety 'Gundega' and breeding line S01085-21(Ffakt<Fcrit). 
In organic growing system tuber yield from cultivars and breeding clones was significantly lower (Ffact> Fcrit) in 2018 in comparison with 2017. For three breeding clones S10063-128, 19922.29 and S 2008-6.5 decrease of tuber yield was not significant (Ffact< $<$ Fcrit).

Earlier germination compared to other varieties and lines was observed to S01085-21 and S03067-33 and the variety 'Rigonda'. In the organic field earlier germination was observed for the varieties 'Rigonda', 'Monta', 'Prelma' and clones S01085-21, S07169-35. 'Gundega'.

According to the results more suitableclones for stress conditions: S010085-21 and S07007.33 and variete

\section{REFERENCES}

1. Dale M.F.B., Mackay G.R.1994. Inheritance of table and processing quality. In potato genetics.CAB internnative, Wallingford, pp. 285-307.

2. Davies A., Jenkins T., Pike A., Shaq J., Carson I., Pollock C,J., Parry MI.1996. Modelling the predicted geographic and economic response of UK cropping systems to climate change scenarios: the case of potatoes. Aspects on Applied Biology, Vol.130, pp. 167178. https://doi.org/10.1111/j.1744-7348.1997.tb05792.x

3. Carter T.R., Saarikko R.A., Niemi K.J. 1996. Assessing the risks and uncertainties of regional crop potential under a changing climate in Finland. Agricultural and Food Sciense in Finland, Vol.5, pp. 329-350. https://doi.org/10.23986/afsci.72750

4. Haverkort A.J.1990. Ecology of potato cropping systems in relation to latituve and altitude. Agricultural systems, Vol. 32, pp. 251-272. https://doi.org/10.1016/0308-521X(90)90004-A

5. Hijmans R.J. 2003. The Effect of Climate Change on global Potato Production. American Jornal of Potato Research, Vol. 80, 271-279. https://doi.org/10.1007/BF02855363

6. Murniece I.2010. Integrated evaluation of potatoes of varieties selected in Latvia. Summary of Doctoral Thesis for Scientific Degree of Doctor of Engineering in Food Science, Jelgava, pp.1-50.

7. Peins D.R., Crawford J.W., Grashoff C., Jefferies R.A., Parter J.R., Marshall B.1996. A simulation study of crop growth ahd development under climate change. Agricultural and Forest Meteorology, Vol. 79, Iss. 4, pp. $271-287$. https://doi.org/10.1016/0168-1923(95)02286-4

8. Reynolds M.P, Ewing,E.E. 1989. Effects of high air and soil temperature stress on growth and tuberization in Solanum tuberosum. Annals of Botany, Vol. 64, Iss. 3, pp. 241-247. https://doi.org/10.1093/oxfordjournals.aob.a087837

9. Rosenzweig C., Phillips J., Goldberg R., Carroll J., Hodges L. 1996. Potential impacts of climate change on citrus and potato production in the US. Agricultural Systems, Vol. 52(4), pp. 455-479. https://doi.org/10.1016/0308-521X(95)00059-E

10. Rukaszewska K. 2017. Impact of heat and drought stresses on size and quality of the potato yield. Plant, Soil and Environment, Vol. 63(1), pp. 40-46. https://doi.org/10.17221/691/2016-PSE

11. Skrabule I. 2003. Investigation of traits meeting processing requirements in potato breeding stock. Summary of Dissertation for Scientific Degree of Dr.agr. Jelgava, pp.1-53.

12. Stol W., de Koning G.H.J, Kooman A.J, van Keulen P.L.H., Penning de Vries F.W.T. 1991. Agro-ecological characterization for potato production. A simulation study at the request of the International Potato Center (CIP), Lima, Peru. CABO-DLO, Report $155.1-47$.

13. L.De Temmerman, Hacor, A., Guns, M.2002. Changing Climate and Potential Impacts on Potato Yield and Quality. European Journal of Agronomy, Vol. 17(4), pp. 233-242. https://doi.org/10.1016/S1161-0301(02)00063-1 